\title{
FETAL ALCOHOL SPECTRUM DISORDERS IN PEDIATRICS FASD AND THE PEDIATRICIAN
}

\author{
Valentina Carito ${ }^{1 *}$, Giovanni Parlapiano ${ }^{2}$, Debora Rasio ${ }^{3}$, Roberto Paparella ${ }^{2}$, Valentina Paolucci², \\ Giampiero Ferraguti ${ }^{4}$, Antonio Greco ${ }^{5}$, Massimo Ralli ${ }^{5}$, Simona Pichini ${ }^{6}$, Marco Fiore ${ }^{1}$, Giovanna \\ Coriale $^{7}$, Mauro Ceccanti ${ }^{7}$, Luigi Tarani ${ }^{2 *}$ \\ ${ }^{1}$ Institute of Cell Biology and Neurobiology, IBCN-CNR, Rome, Italy \\ ${ }^{2}$ Department of Pediatrics, Medical Faculty, Sapienza University of Rome, Italy \\ ${ }^{3}$ San Raffaele Roma, Open University, Rome, Italy \\ ${ }^{4}$ Department of Experimental Medicine, Sapienza University of Rome, Italy \\ ${ }^{5}$ Department of Sense Organs, Sapienza University of Rome, Italy \\ ${ }^{6}$ National Centre on Addiction and Doping, Istituto Superiore di Sanità, Rome, Italy, \\ ${ }^{7}$ Centro Riferimento Alcologico Regione Lazio, Sapienza University of Rome, Italy
}

Fetal alcohol syndrome (FAS) is a complex and malformative condition due to the teratogenic effect of alcohol consumed during pregnancy. Several epidemiological studies have shown that maternal alcohol use during pregnancy is the most common preventable cause of mental retardation in childhood. The effects of alcohol on the fetus range from abortion to a spectrum of clinical manifestations called Fetal Alcohol Spectrum Disorders (FASD) that includes partial FAS (PFAS), neonatal Alcohol Related Birth Defects (ARBD) and Alcohol Related Neurodevelopmental Disorders (ARND) up to the most severe disease which is the so-called FAS. Biomed Rev 2018; 29: 27-35

Keywords: Fetal alcohol spectrum disorders, alcohol, mental retardation, developmental disabilities

\section{Key messages (Highlights)}

1) FASD represents the most common acquired mental retardation, which is totally preventable.

2) The threshold dose of teratogenic alcohol damage is not known, therefore absolute abstention during pregnancy is indicated.

3) The diagnosis of FASD is "by exclusion" and is based essentially on clinical suspicion and confirmation of alcohol intake during pregnancy, therefore all genetic conditions with similar clinical characteristics must be sought.

Received 5 December 2018, revised 16 December 2019, accepted 17 December 2018.

*Corresponding authors:

Dr. Valentina Carito, PhD, Institute of Cell Biology and Neurobiology, IBCN-CNR Rome, Italy

E-mail: valentina.carito@gmail.com

Prof. Luigi Tarani, Department of Pediatrics, Medical Faculty, Sapienza University of Rome, Italy

E-mail: luigi.tarani@uniroma1.it 


\section{INTRODUCTION}

Fetus alcohol syndrome (FAS) is a complex malformative condition of the newborn and the child, described by Lemoine (1) and classified by K. Jones $(2,3)$, due to the teratogenic effect of alcohol taken during pregnancy (4-16). It is the most common cause of mental retardation acquired in childhood, therefore totally avoidable, through the complete abstention of the pregnant woman from the consumption of alcohol. The effects of alcohol on the fetus range from the absence of damage to abortion, including a spectrum of clinical manifestations called FASD (Fetal Alcohol Spectrum Disorders) which, in addition to FAS, includes partial FAS (PFAS), associated neonatal congenital defects (Alcohol Related Birth Defects, ARBD) and neurological development disorders (Alcohol Related Neurodevelopmental Disorders, ARND) (17). Although FASD is a common cause of disability, there are still no definite data on its incidence and prevalence in Italy or in the world, but only sporadic reports. This probably leads to an underestimation of the problem and does not facilitate the correct diagnosis and the possible rehabilitation of numerous children with mental retardation. However, the global prevalence of FASD is about $0.77 \%$, the European prevalence is $0.19 \%$, while in the US it is about $2-5 \%$. The only Italian data concerns the prevalence in Lazio, which for the FAS is 3.7-7.4:1000 and for the FASD is $2-4 \%$ (18-22).

\section{WHY CAN THE PEDIATRICIAN SUSPECT IT?}

In the neonatal age, FAS can be suspected in the presence of a small gestational age with microcephaly and typical dysmorphisms (23-25). The microcephaly data is salient because the preterm newborns are generally relatively macrocephalic. During childhood, the diagnosis is easier because, in addition to the growth defect and facial dysmorphic signs, psychomotor retardation, behavioral disorders and attention and concentration deficits can be detected. In adolescence, to the typical signs of the pediatric age can be added behavioral, scholastic and, above all, social problems.

The pediatrician should refine the diagnostic sensitivity to understand the behavior of the mothers, which demonstrate responsibility, control, balance, care and attention to the newborn. Indeed, it has been shown that mothers who have substantial defects in these spheres, are those who drink even during breastfeeding, exposing the infant to an increased risk of impaired abilities at 6 years (26), even if they did not drink during pregnancy. In fact, the alcohol for 30-60 min after ingestion, maintains in the milk the same levels of maternal blood, in quantities equal to 5-6\% of the ingested dose and with a half capacity to be metabolized by the newborn.

\section{CLINICAL CRITERIA FOR DIAGNOSIS}

Due to the lack of diagnostic genetic or biochemical tests, the decisive step in identifying a child with FASD is to ascertain maternal alcohol consumption during pregnancy (27-32). The absence of this data, very often difficult to obtain due to the guilty feelings of mothers, however, does not exclude the diagnosis, which must be formalized following the recent guidelines $(33,34)$ that are based on the multidisciplinary approach to the mother-child dyad and aimed at analyzing 3 essential aspects of the syndrome (26, 35-37):

1) Morphological abnormalities of the newborn,

2) Neuropsychological, intellectual and social development of the child,

3) Maternal risk factors.

The diagnostic guidelines subdivide the FASD in various forms.

\section{$\underline{I}$ - FAS (all A-D criteria required)}

With or without confirmation of maternal intake of alcohol during pregnancy

A. Presence of two or more facial abnormalities between:

1. Short palpebral fissures $(<10$ th percentile)

2. Thin upper lip (score 4 or 5 )

3. Long and flat philtrum (score 4 or 5 )

B. Pre-postnatal growth rate (height and / or weight $<10$ th percentile per age)

C. Microcephaly or cerebral structural anomalies or recurrent non-febrile convulsions

D. Neurobehavioral deficits (< or $>$ of 3 years)

$<3$ years: mental retardation: > 1.5 SD below average

$>3$ years

1) With cognitive defect

a) Global: general conceptual ability or verbal, spatial, performance IQ:

$>1.5 \mathrm{SD}$ below average

b) At least 1 neuro-behavioral domain among, executive functions, language, memory, visualspatial ability: > 1.5 SD below average

2) With behavioral disorders, without cognitive defect. Deficit in at least 1 domain between mood regulation, attention, control of the pulses: $>1.5 \mathrm{SD}$ below the average 


\section{II - partial FAS}

Confirmation of maternal alcohol intake during pregnancy:

A-B criteria required

Without confirmation, required A-C criteria

A. Presence of two or more of the facial anomalies (point A of the complete FAS)

B. Neurobehavioral deficit (point D of the complete FAS)

C. Pre- and/or postnatal growth retardation

III - ARND required criteria A and B (diagnosis cannot be placed in children $<3$ years)

A. Confirmation of maternal intake of alcohol during pregnancy

B. Cognitive-behavioral abnormalities (point $\mathrm{D}$ of the complete FAS)

$\underline{I V-\mathrm{ARBD}}$ required criteria $\mathrm{A}$ and $\mathrm{B}$

A. Confirmation of maternal intake of alcohol during pregnancy

B. Congenital structural defects (one or more of the heart, kidneys, skeletal, ears, eyes and minor anomalies)

\section{CLINICAL PICTURE AND MEDICAL COMPLICATIONS}

Growth retardation: individuals with FASD, almost constantly, show postnatal growth retardation that occurs during the prenatal period because exposure to fetal alcohol, especially in the third trimester, strongly reduces somatic development. Infants may be small for gestational age and remain below the stature average even during the development. Some children with FASD, probably because they were not exposed to alcohol in the last trimester, may have normal growth parameters but, secondarily, develop learning and cognitive deficits.

\section{Facial anomalies}

Subjects with FAS have 3 major specific abnormalities such as: short palpebral fissures (equal to or lower than the 10th percentile), elongated and flattened nasolabial philtrum and thin upper lip. They may also have minor associated dimorphisms, such as: epicanthus, hypertelorism, flat nasal root with a short nose with antiverse nostrils, hypoplasia of the cheekbones, anomalies of positioning of the ears with a "railway track" appearance of the antihelix cartilage and micrognathia. (Fig. 1)

The identification of the three main facial changes, typical of FASD, can be performed using some standard reference guides, such as the lips and philtrum, (Fig. 2) that transform some clinical aspects into numerical data (score 1-5) and with the aid of the percentiles of growth percentages, by age and sex, of the palpebral fissures, interpupillary and intercantal distances and of the filter, for the detection of which is necessary to have a rigid ruler, possibly transparent.

\section{Structural Congenital Defects}

These include anomalies of various organs such as:

- Heart: (25-50\%): inter-atrial or inter-ventricular defects, cono-truncal anomalies or large vessels.

- Kidneys (4\%): aplasia, hypoplasia, renal dysplasias, horseshoe kidneys, rheno-ureteral duplications.

- Skeleton: with radio-ulnar synostosis, vertebral segmentation defects with cervical vertebrae fusion (50\%), ankylosis of large joints, scoliosis (15\%).

- Ears: mixed (90\%) or sensorineural (30\%) hearing loss.

- Eyes: microphthalmia, strabismus, palpebral ptosis and retinal vascular anomalies with associated visual defect.

- Teeth: frequent caries, ogival palate and Class III malocclusion with growth.

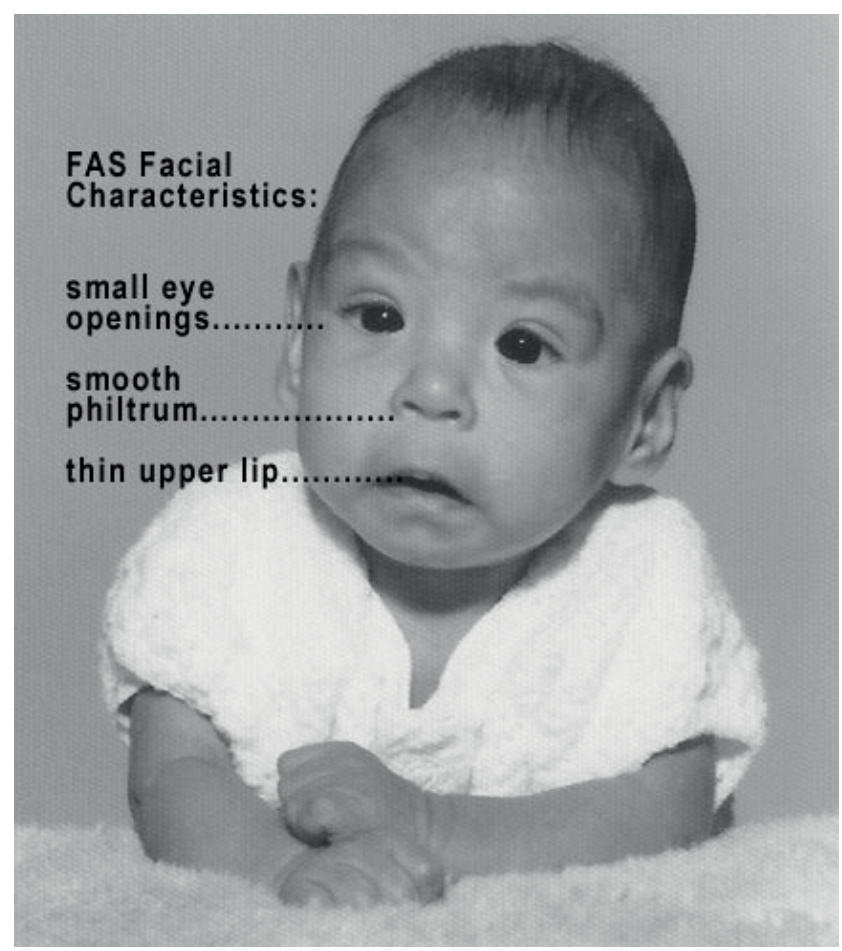

Figure 1. Standard guide for the lip and the philtrum (SCORE 1-2 Normal; 3-5 Possible FAS). 


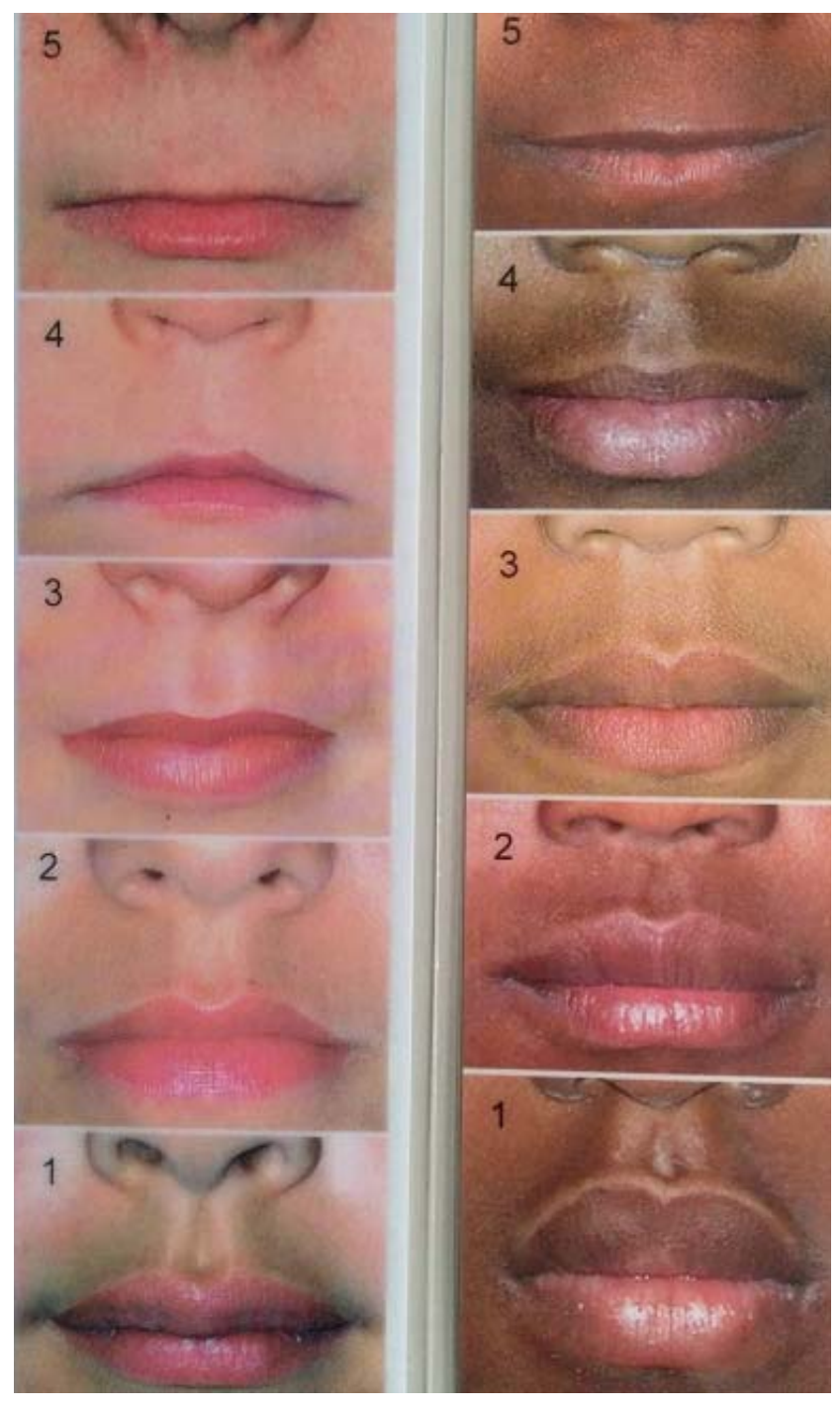

Figure 2. Typical facial signs of FAS children with essential characteristics such as: the short palpebral fissures, the elongated and flattened nasolabial philtrum and the thin upper lip. The dysmorphologic parameters must be detected at all ages, but if the patient's facial signs have eased over time, the diagnosis of facial anomalies should be based on the period in which they were most expressed, possibly with the help of photos. In fact, it is important to observe how the facies of FAS sufferers remain basically unchanged over time.
- Minor dysmorphic anomalies such as: hypoplastic nails, brevity and clinodactyly of the fifth finger, camptodactyly, handheld "hockey stick" and pectus excavatum/carinatum.

\section{Abnormalities of the Central Nervous System}

Numerous studies on the damage due to itrauterine exposure to alcohol show a range of short-term and long-term cognitive and behavioral outcomes deriving from structural and functional central nervous system abnormalities.

The main structural alteration of FASD is microcephaly, often accompanied by low overall growth. Magnetic resonance imaging (MRI) studies show an overall reduction in brain volume and a disorganization of the central nervous system (CNS) (38-50), with specific structural anomalies of alcohol vulnerable areas such as corpus callosum (agenesis, hypoplasia), cerebral cortex, cerebellum, caudate nucleus and hippocampus have been correlated with specific functional alterations (51-54).

Functional disorders include neurological signs such as spasticity, asymmetries in reflexes and, above all, seizures, whose incidence is not yet clear but which involve confirmation with electroencephalogram (EEG) and possibly therapy (55-59).

\section{CONFIRMATION EXAMS}

The definition of dysmorphic signs requires that precise measurements of stature, weight and cranial circumference are made, as well as the assessment of the length of the eyelid slits and of the philtrum. All these data are pathological if they are below the 10th percentile. Also, the appearance of the filter and of the upper lip, which are qualitative data, have been made measurable as quantitative data by the use of the LipPhiltrum Guide. Once a syndromic picture is suspected, it is advisable to obtain confirmation of maternal intake of alcohol during pregnancy (maternal risk factors, adoption from Eastern European countries) and to search for congenital anomalies associated with brain, heart and abdominal ultrasounds, X-rays of the skeleton and brain MRI, EEG, audiometric test and eye examination, as well as to perform the genetic screening tests such as the examination of the karyotype and the CGH-array $(60,61)$. In this way, it is possible to make the differential diagnosis with the syndromes that have signs in common, such as chromosomal diseases and micro-deletions/duplications or other genetic syndromes (Table 1). 
Table 1. Differential FASD diagnosis versus other syndromes

\begin{tabular}{|c|c|c|}
\hline Syndromes & Common signs with FASD & Differential features \\
\hline Aarskog Syndrome & $\begin{array}{l}\text { Small saddle nose, anteverse nostrils, } \\
\text { ample philtrum, hypertelorism }\end{array}$ & $\begin{array}{l}\text { Round face, palpebral ptosis, fold under } \\
\text { the lower lip, dental rash problems }\end{array}$ \\
\hline Williams Syndrome & $\begin{array}{l}\text { Short palpebral fissures, anteverse nostrils, } \\
\text { elongated philtrum, epicanthus, saddle } \\
\text { nose }\end{array}$ & $\begin{array}{l}\text { Wide mouth, star pattern of iris, } \\
\text { periorbital swelling, cartilage disorders }\end{array}$ \\
\hline Noonan Syndrome & $\begin{array}{l}\text { Lowered nasal bridge, hypertelorism, } \\
\text { epicanthus }\end{array}$ & $\begin{array}{l}\text { Keratoconus, palpebral ptosis, broad } \\
\text { mouth with protrusion of the upper lip }\end{array}$ \\
\hline Dubowitz Syndrome & $\begin{array}{l}\text { Short palpebral fissures, hypertelorism, } \\
\text { epicanthus }\end{array}$ & $\begin{array}{l}\text { Low supraorbital ridge with nose bridge } \\
\text { at the level of the forehead }\end{array}$ \\
\hline Brachmann-De Lange Syndrome & $\begin{array}{l}\text { Elongated philtrum, thinned upper lip, } \\
\text { depressed nasal bridge }\end{array}$ & $\begin{array}{l}\text { Single bush eyebrow along the forehead, } \\
\text { long eyelashes, short limbs, acute arch } \\
\text { palate }\end{array}$ \\
\hline Toluene embryopathy & $\begin{array}{l}\text { Short palpebral fissures, median face } \\
\text { hypoplasia, thinned upper lip }\end{array}$ & $\begin{array}{l}\text { Micrognathia, open front fontanelle, hair } \\
\text { anomalies, bifrontal narrowing }\end{array}$ \\
\hline $\begin{array}{l}\text { Fetal Hydantoin Syndrome, also } \\
\text { called Fetal Dilantin Syndrome }\end{array}$ & Hypertelorism, depressed nasal bridge & Short nose with upper arched lip \\
\hline Fetal Valproate Syndrome & $\begin{array}{l}\text { Anteverse niches, elongated philtrum, } \\
\text { hypertelorism }\end{array}$ & $\begin{array}{l}\text { High forehead, infraorbital fold, small } \\
\text { mouth }\end{array}$ \\
\hline $\begin{array}{l}\text { Effects on the fetus of maternal } \\
\text { phenylketonuria }\end{array}$ & $\begin{array}{l}\text { Epicanthus, short palpebral rhymes, } \\
\text { flattened philtrum, thin upper lip }\end{array}$ & $\begin{array}{l}\text { Small saddle nose, prominent glabella, } \\
\text { rounded face }\end{array}$ \\
\hline
\end{tabular}

In fact, a diagnosis of FASD in a child with disability cannot be automatically set-up simply because the mother has taken alcohol during pregnancy and, especially if this confirmation is missing, the diagnosis of FASD must be considered as a diagnosis of exclusion $(27,28,62)$.

\section{INTELLECTUAL PROGNOSIS AND SURVIVAL}

In patients with FASD, when mental retardation is present, it persists, but with improvements related to rehabilitation therapies. Psycho-behavioral problems, if not recognized and early treated, can promote the deterioration of quality of life. Long-lasting mental retardation could overlap with alcohol use disorders during the adult life (63-66).

It was found (67-69) that among people aged 6 to 51 years affected by FASD:

- $94 \%$ have mental health problems and in $23 \%$ of these people mental illness requires hospital assistance
- $83 \%$ of adults have problems with addiction

- $79 \%$ of adults have employment problems

Instead, in boys over the age of 12 it has been reported that:

- $61 \%$ have a disruptive school experience

- $60 \%$ have problems with the law

- $49 \%$ assume inappropriate sexual behavior

- $35 \%$ have alcohol/drug problems

\section{KNOWN MEDICAL COMPLICATIONS}

Although recently the use of alcohol in pregnancy has been correlated with an increased risk of sudden infant death syndrome (70), the main complications attributable to FASD frameworks are mainly related to neurocognitive and behavioral problems. Among the cognitive deficits, the most common are the linguistic difficulties, both of production and of understanding, and the disturbances of the attention (71). However, mental retardation is not a constant feature of the 
syndrome because the child's IQ can vary from a normal range to a severe disability. Deficits in executive functions (gradual reasoning, planning, judgment, problem solving, monitoring) and behavioral disorders (difficulty in taking appropriate behavior, emotional lability, poor academic performance and lack of social interaction) are very frequent and enormously impair social adaptation (72).

\section{CONCLUSION}

The issue of lifelong disabilities caused by alcohol drinking during pregnancy is quite problematic at familial, individual and societal level. As far as a nontoxic consumption behavior during gestation cannot be established, for the extremely individual conditions of vulnerability to alcohol (73), the only suggestion for women planning pregnancies, or during gestation and lactation is to totally avoid the consumption of alcoholic beverages.

\section{CONFLICT OF INTEREST STATEMENT}

The authors certify that they have no affiliations with or involvement in any organization with any financial interest in the subject matter discussed in this review article.

\section{ACKNOWLEDGEMENTS}

We apologize to the authors of many relevant articles that were not quoted here for reasons of brevity.

\section{REFERENCES}

1. Lemoine P, Harousseau H, Borteyru JP, Menuet JC. Les enfants des parents alcoholiques: anomolies observées a propos de 127 cas. Ouest Med 1968; 8:476-482.

2. del Campo M, Jones KL. A review of the physical features of the fetal alcohol spectrum disorders. Eur J Med Genet 2017; 60:55-64. DOI:10.1016/j.ejmg.2016.10.004

3. Peadon E, Rhys-Jones B, Bower C, Elliott EJ. Systematic review of interventions for children with Fetal Alcohol Spectrum Disorders. BMC Pediatr 2009; 9:35. DOI:10.1186/1471-2431-9-35

4. Fiore M, Laviola G, Aloe L, di Fausto V, Mancinelli R, Ceccanti M. Early exposure to ethanol but not red wine at the same alcohol concentration induces behavioral and brain neurotrophin alterations in young and adult mice. Neurotoxicology 2009; 30:59-71. DOI:10.1016/j. neuro.2008.11.009

5. Fiorentino D, Carito V, Solombrino S, Giovanna C, Scamporrino MCM, Ciolli P, et al. Alcohol consumption during pregnancy: Intervention guidance for the prevention of fetal alcohol spectrum disorders. Scr Sci Medica 2017; 49:9-21. DOI:10.14748/ssm. v49i4.4107

6. Ciafre S, Fiore M, Ceccanti M, Messina MP, Tirassa P, Carito V. Role of neuropeptide tyrosine (NPY) in ethanol addiction. Biomed Rev 2016; 27:27-39. DOI:10.14748/ bmr.v27.2110

7. Ciafre' S, Carito V, Ferraguti G, Greco A, Chaldakov GN, Fiore M, Ceccanti M. How alcohol drinking affects our genes: an epigenetic point of view. Biochem Cell Biol 2018;bcb-2018-0248. DOI:10.1139/bcb-2018-0248

8. Ceccanti M, Coccurello R, Carito V, Ciafrè S, Ferraguti G, Giacovazzo G, et al. Paternal alcohol exposure in mice alters brain NGF and BDNF and increases ethanolelicited preference in male offspring. Addict Biol 2016; 21:776-787. DOI:10.1111/adb.12255

9. Coriale G, Fiorentino D, Lauro FDI, Marchitelli R, Scalese B, Fiore M, et al. Fetal Alcohol Spectrum Disorder FASD;: Neurobehavioral profile, indications for diagnosis and treatment. Riv Psichiatr 2013; 48:359-369. DOI:10.1708/1356.15062

10. Ceccanti M, De Nicolò S, Mancinelli R, Chaldakov G, Carito V, Ceccanti M, et al. NGF and BDNF long-term variations in the thyroid, testis and adrenal glands of a mouse model of fetal alcohol spectrum disorders. Ann Ist Super Sanita 2013; 49:383-390. DOI:10.4415/ANN-1304-11

11. Ceccanti M, Mancinelli R, Tirassa P, Laviola G, Rossi S, Romeo M, Fiore M. Early exposure to ethanol or red wine and long-lasting effects in aged mice. A study on nerve growth factor, brain-derived neurotrophic factor, hepatocyte growth factor, and vascular endothelial growth factor. Neurobiol Aging 2012; 33:359-367. DOI:10.1016/j.neurobiolaging.2010.03.005

12. Fiore M, Mancinelli R, Aloe L, Laviola G, Sornelli F, Vitali M, Ceccanti M. Hepatocyte growth factor, vascular endothelial growth factor, glial cell-derived neurotrophic factor and nerve growth factor are differentially affected by early chronic ethanol or red wine intake. Toxicol Lett 2009; 188:208-213. DOI:10.1016/j.toxlet.2009.04.013

13. De Nicolò S, Carito V, Fiore M, Laviola G. Aberrant behavioral and neurobiologic profiles in rodents exposed to ethanol or red wine early in development. Curr Dev Disord Reports 2014; 1:173-180. DOI:10.1007/s40474014-0023-5 
14. Ciafrè $S$, Carito V, Tirassa P, Ferraguti G, Attilia ML, Ciolli $\mathrm{P}$, et al. Ethanol consumption and innate neuroimmunity. Biomed Rev 2017; 28:49-61. DOI:10.14748/bmr. v28.4451

15. Ferraguti G, Ciolli P, Carito V, Battagliese G, Mancinelli $\mathrm{R}$, Ciafrè $\mathrm{S}$, et al. Ethylglucuronide in the urine as a marker of alcohol consumption during pregnancy: Comparison with four alcohol screening questionnaires. Toxicol Lett 2017; 275:49-56. DOI:10.1016/j.toxlet.2017.04.016

16. Carito V, Ceccanti M, Ferraguti G, Coccurello R, Ciafrè S, Tirassa P, Fiore M. NGF and BDNF alterations by prenatal alcohol exposure. Curr Neuropharmacol 2017; 15: DOI: 10.2174/1570159X15666170825101308

17. May PA, Baete A, Russo J, Elliott AJ, Blankenship J, Kalberg WO, et al. Prevalence and characteristics of Fetal Alcohol Spectrum Disorders. Pediatrics 2014; 134:855-866. DOI:10.1542/peds.2013-3319

18. May PA, Fiorentino D, Coriale G, Kalberg WO, Eugene Hoyme H, Aragón AS, et al. Prevalence of children with severe fetal alcohol spectrum disorders in communities near Rome, Italy: New estimated rates are higher than previous estimates. Int J Environ Res Public Health 2011; 8:2331-2351. DOI:10.3390/ijerph8062331

19. Aragón AS, Coriale G, Fiorentino D, Kalberg WO, Buckley D, Phillip Gossage J, et al. Neuropsychological characteristics of Italian children with fetal alcohol spectrum disorders. Alcohol Clin Exp Res 2008; 32:19091919. DOI:10.1111/j.1530-0277.2008.00775.x

20. May PA, Fiorentino D, Phillip Gossage J, Kalberg WO, Eugene Hoyme H, Robinson LK, et al. Epidemiology of FASD in a province in Italy: Prevalence and characteristics of children in a random sample of schools. Alcohol Clin Exp Res 2006; 30:1562-1575. DOI:10.1111/j.15300277.2006.00188.x

21. Ceccanti M, Fiorentino D, Coriale G, Kalberg WO, Buckley D, Hoyme HE, et al. Maternal risk factors for fetal alcohol spectrum disorders in a province in Italy. Drug Alcohol Depend 2014; 145:201-208. DOI:10.1016/j. drugalcdep.2014.10.017

22. Kodituwakku P, Coriale G, Fiorentino D, Aragón AS, Kalberg WO, Buckley D, et al. Neurobehavioral characteristics of children with fetal alcohol spectrum disorders in communities from Italy: Preliminary results. Alcohol Clin Exp Res 2006; 30:1551-1561. DOI:10.1111/ j.1530-0277.2006.00187.x

23. Hassler JA, Moran DJ. Effects of ethanol on the cytoskeleton of migrating and differentiating neural crest cells: possible role in teratogenesis. J Craniofac Genet Dev Biol Suppl 1986; 2:129-136.

24. Cranston ME, Mhanni AA, Marles SL, Chudley AE. Concordance of three methods for palpebral fissure length measurement in the assessment of fetal alcohol spectrum disorder. Can J Clin Pharmacol 2009; 16:e234-e241.

25. Pooley M. Saving VAT on building work. Elder Care 1993; 5:18. DOI:10.1093/ejo/cji110

26. Gibson L, Porter M. Drinking or smoking while breastfeeding and later cognition in children. Pediatrics 2018; 142:e20174266. DOI:10.1542/peds.2017-4266

27. Chudley AE, Conry J, Cook JL, Loock C, Rosales T, Leblanc N. guidelines for diagnosis: Identifying fetal alcohol spectrum disorder in primary care. $J$ Med Assoc Canada 2005; 172:S1-S21. DOI:10.1503/ cmaj.1040302

28. Burd L, Klug MG, Li Q, Kerbeshian J, Martsolf JT. Diagnosis of fetal alcohol spectrum disorders: A validity study of the fetal alcohol syndrome checklist. Alcohol 2010; 44:605-614. DOI:10.1016/j. alcohol.2009.08.010

29. Manning MA, Eugene Hoyme H. Fetal alcohol spectrum disorders: A practical clinical approach to diagnosis. Neurosci Biobehav Rev 2007; 31:230-238. DOI:10.1016/j. neubiorev.2006.06.016

30. Vagnarelli F, Palmi I, García-Algar O, Falcon M, Memo L, Tarani L, et al. A survey of Italian and Spanish neonatologists and paediatricians regarding awareness of the diagnosis of FAS and FASD and maternal ethanol use during pregnancy. BMC Pediatr 2011; 11:51. DOI:10.1186/1471-2431-11-51

31. Riley EP, Infante MA, Warren KR. Fetal alcohol spectrum disorders: An overview. Neuropsychol Rev 2011; 21:7380. DOI:10.1007/s11065-011-9166-X

32. Astley SJ, Aylward EH, Olson HC, Kerns K, Brooks A, Coggins TE, et al. Magnetic resonance imaging outcomes from a comprehensive magnetic resonance study of children with fetal alcohol spectrum disorders. Alcohol Clin Exp Res 2009; 33:1671-1689. DOI:10.1111/j.15300277.2009.01004.x

33. Hoyme HE, Kalberg WO, Elliott AJ, Blankenship J, Buckley D, Marais A-S, et al. Updated clinical guidelines for diagnosing Fetal Alcohol Spectrum Disorders. Pediatrics 2016; 138:e20154256-e20154256. DOI:10.1542/peds.2015-4256 
34. Viljoen D, Louw JG, Lombard C, Olivier L. Comparing diagnostic outcomes of children with fetal alcohol syndrome in South Africa with diagnostic outcomes when using the updated Institute of Medicine diagnostic guidelines. Birth Defects Res 2018; 110:1335-1342. DOI:10.1002/bdr2.1399

35. Elgen I, Bruaroy S, Laegreid LM. Lack of recognition and complexity of foetal alcohol neuroimpairments. Acta Paediatr Int J Paediatr 2007; 96:237-241. DOI:10.1111/ j.1651-2227.2007.00026.x

36. Autti-Rämö I, Fagerlund Å, Ervalahti N, Loimu L, Korkman M, Hoyme HE. Fetal alcohol spectrum disorders in Finland: Clinical delineation of 77 older children and adolescents. Am J Med Genet 2006; 140 A:137-143. DOI:10.1002/ajmg.a.31037

37. Fiorentino D, Coriale G, Spagnolo PA, Prastaro A, Attilia ML, Mancinelli R, Ceccanti M. Fetal alcohol syndrome disorders: Experience on the field. The Lazio study preliminary report. Ann Ist Super Sanita 2006; 42:53-57.

38. Astley SJ, Olson HC, Kerns K, Brooks A, Aylward EH, Coggins TE, et al. Neuropyschological and behavioral outcomes from a comprehensive magnetic resonance study of children with fetal alcohol spectrum disorders. Can J Clin Pharmacol 2009; 16:e178-201.

39. Donald KA, Eastman E, Howells FM, Adnams C, Riley EP, Woods RP, et al. Neuroimaging effects of prenatal alcohol exposure on the developing human brain: A magnetic resonance imaging review. Acta Neuropsychiatr 2015; 27:251-269. DOI:10.1017/neu.2015.12

40. Woods KJ, Jacobson SW, Molteno CD, Jacobson JL, Meintjes EM. Altered parietal activation during nonsymbolic number comparison in children with prenatal alcohol exposure. Front Hum Neurosci 2018; 11:627. DOI:10.3389/fnhum.2017.00627

41. Biffen SC, Warton CMR, Lindinger NM, Randall SR, Lewis CE, Molteno CD, et al. Reductions in corpus callosum volume partially mediate effects of prenatal alcohol exposure on IQ. Front Neuroanat 2018; 11:132. DOI:10.3389/fnana.2017.00132

42. Suttie M, Wozniak JR, Parnell SE, Wetherill L, Mattson $\mathrm{SN}$, Sowell ER, et al. Combined face-brain morphology and associated neurocognitive correlates in fetal alcohol spectrum disorders. Alcohol Clin Exp Res 2018; 42:17691782. DOI:10.1111/acer. 13820

43. Migliorini R, Moore EM, Glass L, Infante MA, Tapert SF, Jones KL, Mattson SN, Riley EP. Anterior cingulate cortex surface area relates to behavioral inhibition in adolescents with and without heavy prenatal alcohol exposure. Behav Brain Res 2015; 292:26-35. DOI:10.1016/j. bbr.2015.05.037

44. Woods KJ, Meintjes EM, Molteno CD, Jacobson SW, Jacobson JL. Parietal dysfunction during number processing in children with fetal alcohol spectrum disorders. NeuroImage Clin 2015; 8:594-605. DOI:10.1016/j. nicl.2015.03.023

45. Infante MA, Moore EM, Bischoff-Grethe A, Migliorini R, Mattson SN, Riley EP. Atypical cortical gyrification in adolescents with histories of heavy prenatal alcohol exposure. Brain Res 2015; 1624:446-454. DOI:10.1016/j. brainres.2015.08.002

46. Fan J, Jacobson SW, Taylor PA, Molteno CD, Dodge NC, Stanton ME, et al. White matter deficits mediate effects of prenatal alcohol exposure on cognitive development in childhood. Hum Brain Mapp 2016; 37:2943-2958. DOI:10.1002/hbm.23218

47. Boronat S, Sánchez-Montañez A, Gómez-Barros N, Jacas C, Martínez-Ribot L, Vázquez E, et al. Correlation between morphological MRI findings and specific diagnostic categories in fetal alcohol spectrum disorders. Eur J Med Genet 2017; 60:65-71. DOI:10.1016/j.ejmg.2016.09.003

48. Wozniak JR, Mueller BA, Mattson SN, Coles CD, Kable JA, Jones KL, et al. Functional connectivity abnormalities and associated cognitive deficits in fetal alcohol Spectrum disorders FASD;. Brain Imaging Behav 2017; 11:14321445. DOI:10.1007/s11682-016-9624-4

49. Kodali VN, Jacobson JL, Lindinger NM, Dodge NC, Molteno CD, Meintjes EM, Jacobson SW. Differential recruitment of brain regions during response inhibition in children prenatally exposed to alcohol. Alcohol Clin Exp Res 2017; 41:334-344. DOI:10.1111/acer.13307

50. Hendrickson TJ, Mueller BA, Sowell ER, Mattson $\mathrm{SN}$, Coles CD, Kable JA, et al. Cortical gyrification is abnormal in children with prenatal alcohol exposure. NeuroImage Clin 2017; 15:391-400. DOI:10.1016/j. nicl.2017.05.015

51. Norman AL, Crocker N, Mattson SN, Riley EP. Neuroimaging and fetal alcohol spectrum disorders. Dev Disabil Res Rev 2009; 15:209-217. DOI:10.1002/ddrr.72

52. Sowell ER, Mattson SN, Kan E, Thompson PM, Riley EP, Toga AW. Abnormal cortical thickness and brain-behavior correlation patterns in individuals with heavy prenatal alcohol exposure. Cereb Cortex 2008; 18:136-144. DOI:10.1093/cercor/bhm039 
53. Fryer SL, Tapert SF, Mattson SN, Paulus MP, Spadoni AD, Riley EP. Prenatal alcohol exposure affects frontalstriatal BOLD response during inhibitory control. Alcohol Clin Exp Res 2007; 31:1415-1424. DOI:10.1111/j.15300277.2007.00443.x

54. Mattson SN, Riley EP. A review of the neurobehavioral deficits in children with fetal alcohol syndrome or prenatal exposure to alcohol. Alcohol Clin Exp Res 1998; 22:279294. DOI:10.1111/j.1530-0277.1998.tb03651.x

55. Burden MJ, Andrew C, Saint-Amour D, Meintjes EM, Molteno CD, Hoyme HE, et al. The effects of fetal alcohol syndrome on response execution and inhibition: An event-related potential study. Alcohol Clin Exp Res 2009; 33:1994-2004. DOI:10.1111/j.15300277.2009.01038.x

56. Coles CD, Li Z. Functional neuroimaging in the examination of effects of prenatal alcohol exposure. Neuropsychol Rev 2011; 21:119-132. DOI:10.1007/ s11065-011-9165-y

57. Kaneko WM, Ehlers CL, Philips EL, Riley EP. Auditory event-related potentials in fetal alcohol syndrome and Down's syndrome children. Alcohol Clin Exp Res 1996; 20:35-42. DOI:10.1111/j.1530-0277.1996.tb01040.x

58. Kaneko WM, Phillips EL, Riley EP, Ehlers CL. EEG findings in fetal alcohol syndrome and Down syndrome children. Electroencephalogr Clin Neurophysiol 1996; 98:20-28. DOI:10.1016/0013-469495;00189-1

59. Mattson SN, Riley EP, Jernigan TL, Ehlers CL, Delis DC, Jones KL, et al. Fetal alcohol syndrome: A case report of neuropsychological, MRI, and EEG assessment of two children. Alcohol Clin Exp Res 1992; 16:1001-1003. DOI:10.1111/j.1530-0277.1992.tb01909.x

60. Turchetta R, Conti G, Marsella P, Orlando MP, Picciotti PM, Frezza S, et al. Universal newborn hearing screening in the Lazio region, Italy. Ital J Pediatr 2018; 44:104. DOI:10.1186/s13052-018-0534-5

61. Ralli M, Rolesi R, Anzivino R, Turchetta R, Fetoni AR. Acquired sensorineural hearing loss in children: current research and therapeutic perspectives. Acta Otorhinolaryngol Ital 2017; 37:500-508. DOI:10.14639/0392-100X-1574

62. Chudley AE, Kilgour AR, Cranston M, Edwards M. Challenges of diagnosis in fetal alcohol syndrome and fetal alcohol spectrum disorder in the adult. Am J Med Genet Part C Semin Med Genet 2007; 145:261-272. DOI:10.1002/ajmg.c.30140
63. Ceccanti M, Coriale G, Hamilton DA, Carito V, Coccurello $\mathrm{R}$, Scalese B, et al. Virtual Morris task responses in individuals in an abstinence phase from alcohol. Can J Physiol Pharmacol 2018; 96:128-136. DOI:10.1139/ cjpp-2017-0013

64. Ceccanti M, Hamilton D, Coriale G, Carito V, Aloe L, Chaldakov G, et al. Spatial learning in men undergoing alcohol detoxification. Physiol Behav 2015; 149:324-330. DOI:10.1016/j.physbeh.2015.06.034

65. Merrick J, Merrick E, Morad M, Kandel I. Fetal alcohol syndrome and its long-term effects. Minerva Pediatr 2006; 58:211-218.

66. O'Leary C, Leonard H, Bourke J, D'Antoine H, Bartu A, Bower C. Intellectual disability: Population-based estimates of the proportion attributable to maternal alcohol use disorder during pregnancy. Dev Med Child Neurol 2013; 55:271-277. DOI:10.1111/dmcn.12029

67. Streissguth AP, O’Malley K. Neuropsychiatric implications and long-term consequences of fetal alcohol spectrum disorders. Semin Clin Neuropsychiatry 2000; 5:177-190. DOI:10.1053/scnp.2000.6729

68. Kelly SJ, Day N, Streissguth AP. Effects of prenatal alcohol exposure on social behavior in humans and other species. Neurotoxicol Teratol 2000; 22:143-149. DOI:10.1016/S0892-036299)00073-2

69. Famy C, Streissguth AP, Unis AS. Mental illness in adults with fetal alcohol syndrome or fetal alcohol effects. Am J Psychiatry 1998; 155:552-554. DOI:10.1176/ ajp.155.4.552

70. O'Leary CM, Jacoby PJ, Bartu A, D'Antoine H, Bower C. Maternal alcohol use and sudden infant death syndrome and infant mortality excluding SIDS. Pediatrics 2013; 131:e770-e778. DOI:10.1542/peds.2012-1907

71. Wilhoit LF, Scott DA, Simecka BA. Fetal Alcohol Spectrum Disorders: Characteristics, complications, and treatment. Community Ment Health J 2017; 53:711-718. DOI:10.1007/s10597-017-0104-0

72. May PA, Blankenship J, Marais AS, Gossage JP, Kalberg WO, Joubert B, et al. Maternal alcohol consumption producing fetal alcohol spectrum disorders (FASD): Quantity, frequency, and timing of drinking. Drug Alcohol Depend 2013; 133:502-512. DOI:10.1016/j. drugalcdep.2013.07.013

73. Ferraguti G, Pascale E. Lucarelli M, Alcohol addiction: a molecular biology perspective. Curr Med Chem 2015; 22:670-684. DOI:10.2174/0929867321666141229103158 